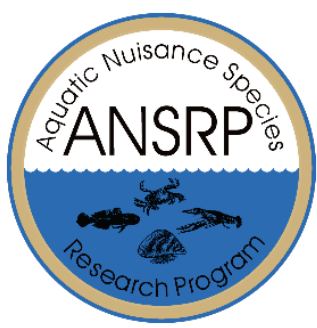

\title{
Observation of Silver Carp Spawning in a Mississippi River Tributary
}

by K. Jack Killgore and Steven G. George

PURPOSE: This technical note seeks to better understand spawning cues of invasive carp for management and control purposes.

BACKGROUND: The Lower Mississippi River Valley (LMRV) is the principal center of abundance for invasive carp initially imported from Asia during the last half of the 1900s to control aquatic vegetation in aquaculture facilities. After escaping into the Lower Mississippi River (LMR), their abundance and range quickly expanded into the Missouri River, Upper Mississippi River, Ohio-Tennessee Rivers, and they now threaten to invade the Great Lakes. A recent study in the LMR reported silver carp to be the dominant catch in hoop nets during the spring and summer, which corresponds to the reproductive season of this species (Killgore and George 2020). Silver carp and their congener, bighead carp, have also been documented in Gulf Coast tributaries as they expand within the southeastern United States (Slack et al. 2016). Silver carp are notable for their jumping ability when agitated by sounds and pose a significant threat to boaters. Both silver and bighead carp have been documented to affect native fishes, including bigmouth buffalo, gizzard shad, and paddlefish (Schrank, Guy, and Fairchild 2003; Phelps et al. 2017; Chick et al. 2020; Kinlock et al. 2020).

Silver carp's reproductive potential and rapid growth rates contribute directly to its expanding density and distribution in North American waters. Silver carp are highly fecund compared to native species (Degrandchamp, Garvey, and Csoboth 2007), and one female can produce over 5,000,000 eggs (Kolar et al. 2005, 22). Fertilized eggs are semibuoyant and require flow to stay afloat until hatching. After hatching, young-of-year move towards backwaters and feed on phytoand zooplankton where their corresponding growth and survival rates are highest (Pongruktham, Ochs, and Hoover 2010). The many flowing streams and rivers in the LMRV provide virtually unlimited spawning sites, and extensive backwaters and lakes provide stable rearing areas with high productivity (Ochs et al. 2019). However, direct observations of spawning silver carp are rare. A better understanding of environmental cues associated with spawning may lead to new and innovative techniques to control the population growth of these invasive species.

We recorded a major spawning event of silver carp in the Tallahatchie River, Mississippi, during April 2019. Spawning activities were apparent and widespread during the period when we had deployed 22 hoop nets to sample benthic fishes for a long-term monitoring project. This technical note describes the morphological characteristics of the channel reach where the majority of spawning occurred, environmental cues associated with the spawning event, and the relative abundance of silver carp compared to native species. 
GEOGRAPHIC SETTING: We sampled three river reaches in the Upper Yazoo Basin: Coldwater River, the Panola-Quitman (PQ) Waterway, and the Tallahatchie River (Figure 1). We sampled the Coldwater River reach approximately $1 \mathrm{mi}(1.6 \mathrm{~km})$ above its confluence with the Tallahatchie River. The PQ Waterway is a constructed conveyance channel that receives water from Sardis Lake and Enid Lake reservoirs, and its sampling reach was also approximately one mile above its confluence with the Tallahatchie River. The Tallahatchie River begins at the confluence of the Coldwater River and PQ Waterway, and the sampling reach was approximately one mile below this juncture. Since all three reaches are influenced by reservoir releases, they flow year-round, while unregulated rivers in the basin may become nonflowing during low-water months. We observed peak spawning activity in April 2019 in the portion of the Tallahatchie reach characterized by a bendway morphology with a sinuosity index of 1.48 (Figure 1). River reaches with sinuosity indices less than 1.0 are straight, while those greater than 1.3 are meandering (Mueller 1968, 373). The Coldwater and PQ Waterway reaches were straightaways with sinuosity index values around 1.0. The sinuosity of the Tallahatchie reach creates more complex currents and eddies compared to the more rectilinear flows in the Coldwater and PQ Waterway reaches. Invasive carp may prefer sinuous reaches to prevent semibuoyant eggs from sinking, which increases mortality in newly spawned eggs. 


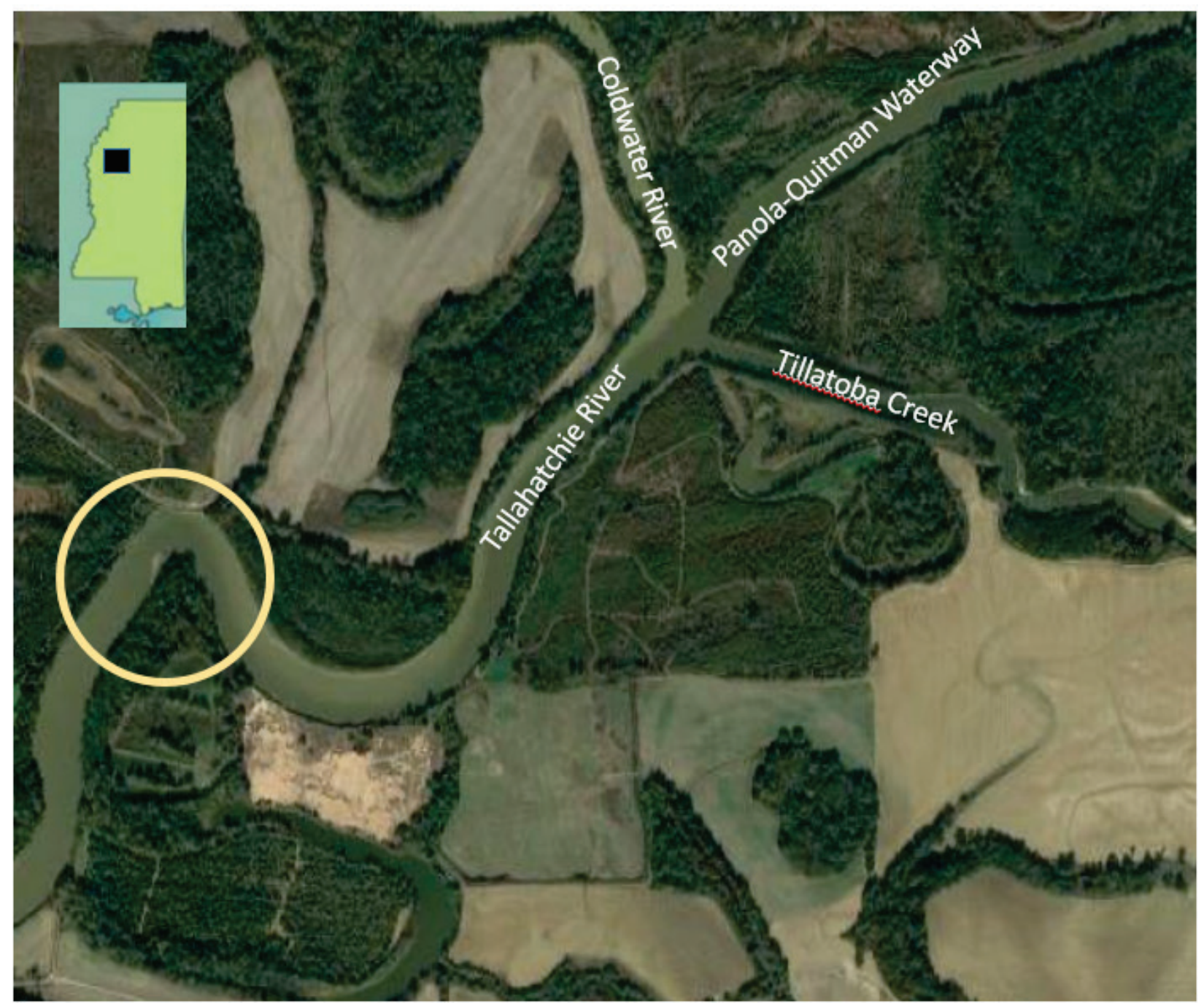

Figure 1. Location of Silver Carp Spawning Site on the Tallahatchie River, Mississippi, below the confluence of the Coldwater River and Panola-Quitman (PQ) Waterway. Circle indicates the sinuous bendway where the majority of spawning activity was observed. Invasive carp may prefer sinuous reaches to prevent semibuoyant eggs from sinking, which increases mortality in newly spawned eggs.

Fish Abundance. We used hoop nets of two sizes to target and sample a wide range of benthic species in the three reaches: $3 \mathrm{ft}$ diameter opening, 7 hoops, $12 \mathrm{ft}$ long, 1 in. square mesh and $4 \mathrm{ft}$ diameter opening, 7 hoops, $15 \mathrm{ft}$ long, 3 in. square mesh. A previous study used the former at the same sites from 1990-1991, and so we compared these data to the present study. Because of flood conditions in the channels, we set hoop nets close to the bank. We deployed 22 unbaited nets during the afternoon of 9 April 2019 and retrieved them the following morning, giving them an average ( \pm 1 standard deviation) soak time of $19.7 \pm 0.6 \mathrm{~h}$. We identified fish in the field, measured their total length, and released them.

For the Coldwater and PQ Waterway reaches, we placed three $3 \mathrm{ft}(0.9 \mathrm{~m})$ diameter nets and three $4 \mathrm{ft}(1.2 \mathrm{~m})$ diameter nets in each reach, for a total of 12 nets. In the Tallahatchie reach, we placed five $3 \mathrm{ft}$ nets and five $4 \mathrm{ft}$ nets, for a total of 10 nets. These same reaches were sampled in 1990 on 
12 March, 26 March, and 19 April at similar water temperatures (that is, $16^{\circ} \mathrm{C}-19^{\circ} \mathrm{C}$ ) using $3 \mathrm{ft}$ hoop nets with the following sample sizes: Tallahatchie -16 nets; Coldwater -8 nets; and PQ Waterway-16 nets, for a total of 40 nets.

We collected a total of 17 species (Table 1). Species richness was higher in 1990 (7-11 species) than 2019 (3-6 species), primarily because of the higher sample size in 1990. However, impacts of invasive carp on species occurrence and abundance between the two decades may also be a contributing factor. Of the four invasive carp species, only common carp were collected in April 1990, whereas four species of carp were collected in April 2019: bighead, common, grass, and silver. Bighead and silver carp were first collected in the Yazoo Basin during the early 1990s, with limited distribution (Douglas et al. 1996). However, silver carp were two to three times more abundant in April 2019 than any other species, with a total of 83 individuals collected overall. Silver carp were most abundant in the Tallahatchie reach, with a total of 55 individuals, followed by 13 grass carp. All four species of carp were in reproductive condition, with milt and eggs expressed upon capture. Numerous silver carp were caught with flaccid skin around the abdomen, indicating a postspawn condition (Figure 2).

Mean total length (mm) of the four species of carp collected in April 2019 ranged from $569 \mathrm{~mm}$ for common carp to $1031 \mathrm{~mm}$ for bighead carp (Table 2). Mean ( \pm standard deviation) length of silver carp was $778 \pm 80 \mathrm{~mm}$. Length frequency distribution showed that the majority of silver carp spawning in the Tallahatchie River occurred between 680-840 mm (Figure 3). Individual silver carp $>900 \mathrm{~mm}$ or $<600 \mathrm{~mm}$ were uncommon. 
ERDC/TN ANSRP-21-1

September 2021

Table 1. Number of fish collected with $3 \mathrm{ft}$ (HN3) and $4 \mathrm{ft}$ (HN4) diameter hoop nets in three river reaches in the Yazoo Delta during April 2019 and March-April 1990. A total of 17 species were collected. Species richness was higher in 1990 (7-11 species) than 2019 (3-6 species), primarily because of the higher sample size in 1990. Invasive carp were not collected in 1990s other than common carp, whereas silver carp were two to three times more abundant in April 2019 than any other species.

\begin{tabular}{|c|c|c|c|c|c|c|c|c|c|c|}
\hline \multirow[b]{2}{*}{$\begin{array}{l}\text { Common } \\
\text { name }\end{array}$} & \multicolumn{3}{|c|}{ HN3: April 2019} & \multicolumn{3}{|c|}{ HN4: April 2019} & \multicolumn{3}{|c|}{ HN3: March-April 1990} & \multirow[b]{2}{*}{ Total } \\
\hline & $\begin{array}{l}\text { Tallahatchie } \\
\mathrm{N}=5\end{array}$ & $\begin{array}{l}\text { Coldwater } \\
\mathrm{N}=3\end{array}$ & \begin{tabular}{|l|}
$\mathrm{PQ}$ \\
Waterway \\
$\mathrm{N}=3$ \\
\end{tabular} & $\begin{array}{l}\text { Tallahatchie } \\
\mathrm{N}=5\end{array}$ & $\begin{array}{l}\text { Coldwater } \\
\mathrm{N}=3\end{array}$ & \begin{tabular}{|l|}
$\mathrm{PQ}$ \\
Waterway \\
$\mathrm{N}=3$
\end{tabular} & $\begin{array}{l}\text { Tallahatchie } \\
\mathrm{N}=16\end{array}$ & $\begin{array}{l}\text { Coldwater } \\
\mathrm{N}=8\end{array}$ & \begin{tabular}{|l|}
$\mathrm{PQ}$ \\
Waterway \\
$\mathrm{N}=16$
\end{tabular} & \\
\hline $\begin{array}{l}\text { American } \\
\text { eel }\end{array}$ & & & & & & & 1 & & 3 & 4 \\
\hline $\begin{array}{l}\text { Bighead } \\
\text { carp }\end{array}$ & & & & 3 & & & & & & 3 \\
\hline $\begin{array}{l}\text { Bigmouth } \\
\text { buffalo }\end{array}$ & & & & & & & & 1 & & 1 \\
\hline $\begin{array}{l}\text { Black } \\
\text { bullhead }\end{array}$ & & & & & & & & 1 & 1 & 2 \\
\hline Blue catfish & 1 & 3 & 1 & & & & 6 & 1 & 2 & 14 \\
\hline Blue sucker & & 2 & & & & & 1 & & 1 & 4 \\
\hline $\begin{array}{l}\text { Channel } \\
\text { catfish }\end{array}$ & & & & & & & 1 & & & 1 \\
\hline $\begin{array}{l}\text { Common } \\
\text { carp }\end{array}$ & 3 & & & & & & 1 & 1 & & 5 \\
\hline $\begin{array}{l}\text { Flathead } \\
\text { catfish }\end{array}$ & & & 3 & & & & 2 & 2 & 3 & 10 \\
\hline $\begin{array}{l}\text { Freshwater } \\
\text { drum }\end{array}$ & & & & & & 1 & 1 & & 2 & 4 \\
\hline $\begin{array}{l}\text { Gizzard } \\
\text { shad }\end{array}$ & & & & & & & 2 & & & 2 \\
\hline Grass carp & 9 & & & 15 & 1 & & & & & 25 \\
\hline $\begin{array}{l}\text { Longnose } \\
\text { gar }\end{array}$ & 2 & & & & & & 4 & 2 & & 8 \\
\hline Paddlefish & & & & & & 1 & & & & 1 \\
\hline $\begin{array}{l}\text { River } \\
\text { carpsucker }\end{array}$ & & & & & & & 2 & & 2 & 4 \\
\hline Silver carp & 14 & & & 55 & 13 & 1 & & & & 83 \\
\hline $\begin{array}{l}\text { Smallmouth } \\
\text { buffalo }\end{array}$ & 5 & 1 & 4 & 5 & 1 & 21 & 2 & 1 & 3 & 43 \\
\hline & & & & & & & & & & \\
\hline $\begin{array}{l}\text { Total } \\
\text { number }\end{array}$ & 34 & 6 & 8 & 78 & 15 & 24 & 23 & 9 & 17 & 214 \\
\hline Mean & 6.8 & 2.0 & 2.7 & 15.6 & 5.0 & 8.0 & 1.4 & 1.1 & 1.1 & 11.9 \\
\hline $\begin{array}{l}\text { Number of } \\
\text { species }\end{array}$ & 6 & 3 & 3 & 4 & 3 & 4 & 11 & 7 & 8 & 17 \\
\hline
\end{tabular}




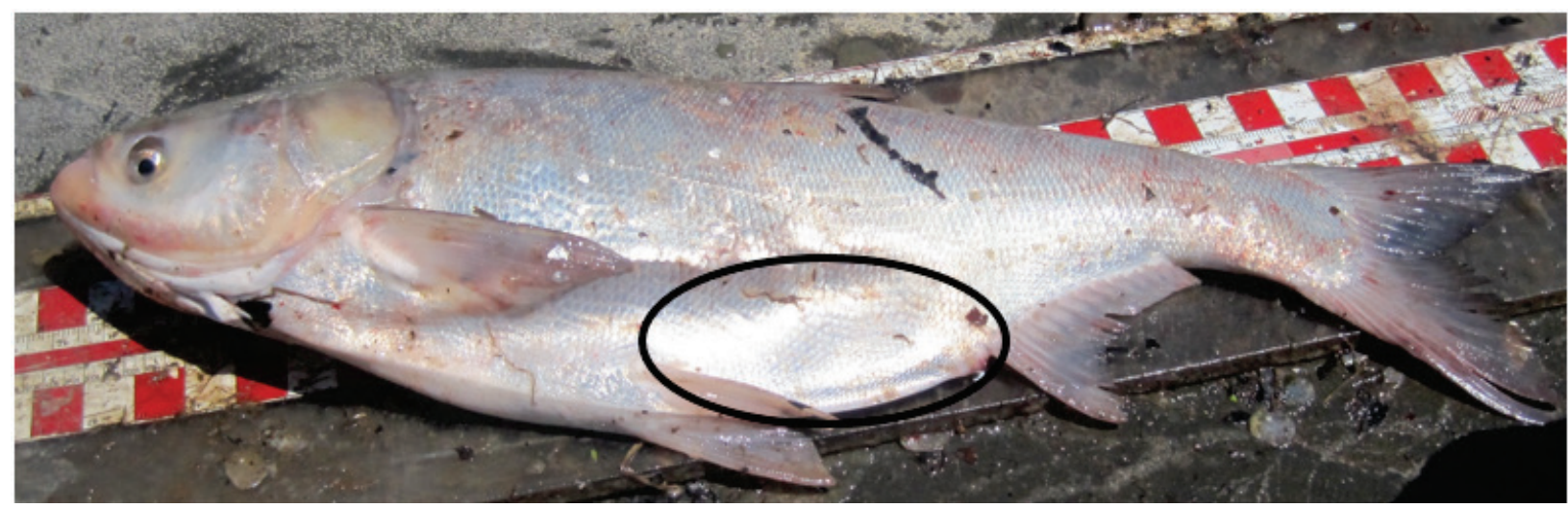

Figure 2. Silver carp female in postspawn condition exhibiting flaccid skin (black circle) after eggs were released.

Table 2. Summary of fish total lengths (in $\mathrm{mm}$ ) for four species of carp collected 9-10 April 2019. Mean lengths ranged from $569 \mathrm{~mm}$ for common carp to $1031 \mathrm{~mm}$ for bighead carp.

\begin{tabular}{|l||l||l||l|l||l||}
\hline \hline Species & N & Mean & $\begin{array}{l}\text { Standard } \\
\text { deviation }\end{array}$ & Minimum & Maximum \\
\hline \hline Bighead carp & 3 & 1031 & 189 & 814 & 1152 \\
\hline Common carp & 3 & 569 & 16 & 552 & 583 \\
\hline Grass carp & 25 & 851 & 76 & 731 & 992 \\
\hline Silver carp & 83 & 778 & 80 & 458 & 1003 \\
\hline \hline
\end{tabular}




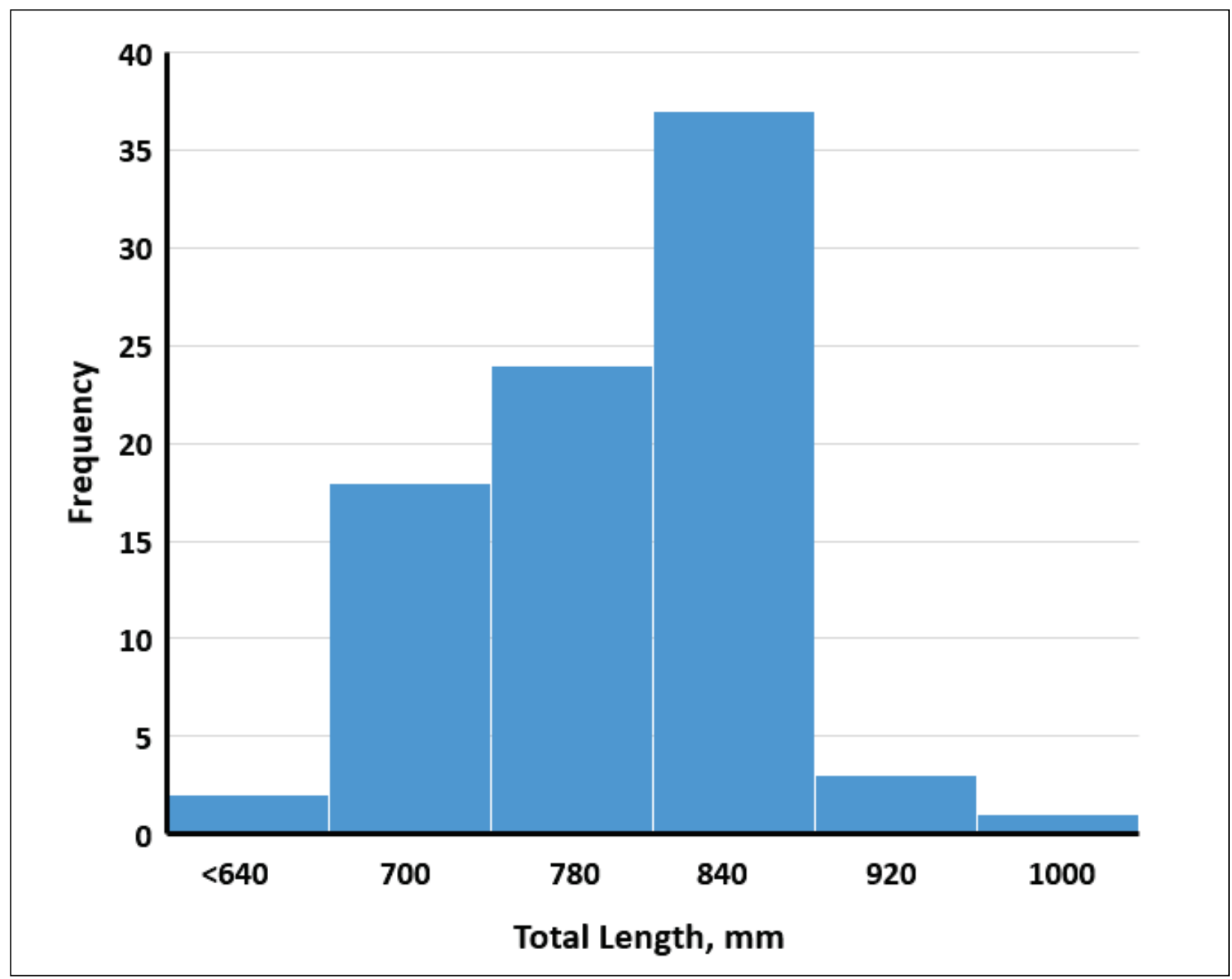

Figure 3. Length frequency of silver carp caught in the Tallahatchie River, 9-10 April 2019. Length frequency distribution showed that the majority of silver carp spawning in the Tallahatchie River occurred between 680-840 mm.

Spawning Cues. Spawning events for silver carp have been reported to be higher in the daytime between 0500 and $2100 \mathrm{~h}$ than at night, and spawning often occurs during the rising limb of the hydrograph (Deters, Chapman, and McElroy 2013). Similar conditions occurred during the observed spawning event in the Tallahatchie River. River stage was cresting from a recent rainstorm and high discharge from the upstream reservoirs during the April 2019 spawning event (Figure 4, upper panel). During this time, water temperature rapidly rose from $14^{\circ} \mathrm{C}$ to $19^{\circ} \mathrm{C}$ over a five-day period (Figure 4, lower panel), which is the reported spawning temperature range of silver carp (Kolar et al. 2007, 25). The rapid rise in water temperature was a result of epilimnetic discharge from the warmer waters of Sardis Lake and Enid Lake reservoirs. All three reaches had water temperatures between $18^{\circ} \mathrm{C}$ and $19^{\circ} \mathrm{C}$ during the spawning event. 


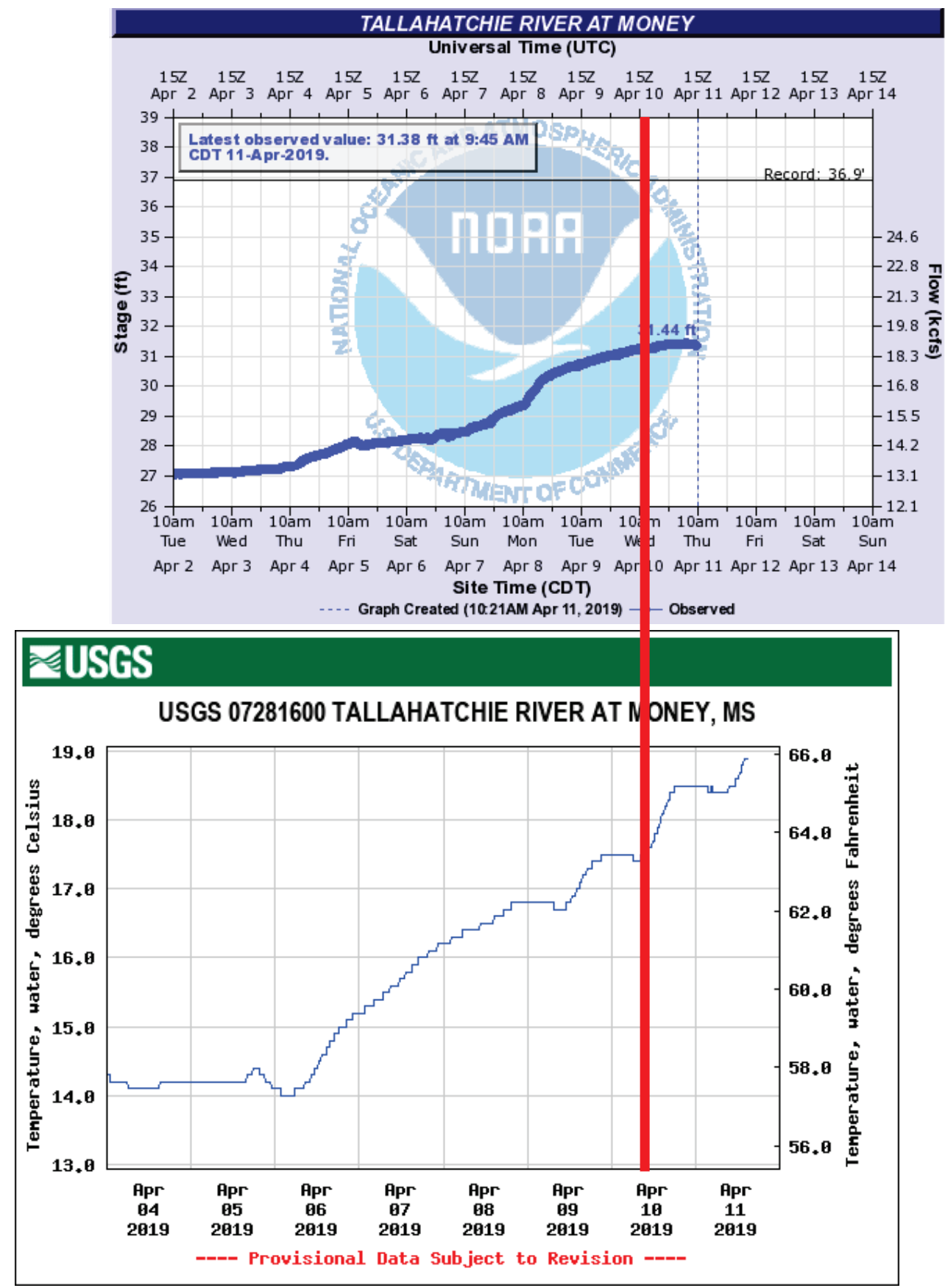

Figure 4. River stage (upper) and water temperature (lower) during the 9-10 April spawning event, Tallahatchie River at Money, Mississippi. Red line denotes sampling date. River stage was cresting and water temperature rapidly rose from $14^{\circ} \mathrm{C}$ to $19^{\circ} \mathrm{C}$ over a five-day period within the reported spawning temperature range of silver carp.

Spawning Behavior. Spawning behavior has been reported in the Yangtze River, China, as referenced in Kolar et al. $(2007,24)$. When silver carp were ready to spawn, ripples appeared on the water surface from spawners chasing each other. About 40 to 80 min later, males and females ascended close to the water surface, chasing each other and shedding eggs and sperm. Silver carp repeatedly used 36 discrete spawning sites within a $1700 \mathrm{~km}$ reach of the Yangtze River, China. 
We observed similar behavior in the Tallahatchie River. Aggregations of three or more silver carp constantly splashed and glided along the surface, and suddenly a caudal fin would emerge from the water for about 5-10 s and point straight up to the sky, at which point presumably eggs and milt were released simultaneously. We observed this activity repeatedly during the two days of our sampling efforts, including while setting and retrieving nets. Although difficult to count, hundreds of these spawning events occurred during that time, most prevalently in the sinuous reach of the Tallahatchie River.

SUMMARY AND MANAGEMENT RECOMMENDATIONS: In all, we collected four species of invasive carp in the Upper Yazoo river channels in April 2019, all in spawning condition. Of the four species, silver carp were most abundant and were continuously observed spawning near the water surface. Peak spawning occurred during a rapid rise in river stage, a rapid rise in water temperature up to $18^{\circ} \mathrm{C}-19^{\circ} \mathrm{C}$, and most commonly in a sinuous river reach with complex hydraulic patterns. Identifying preferred spawning locations and spawning cues of silver carp and other invasive species should be considered in regulated rivers. Modifying the operation of dams during periods of preferred spawning temperatures for carp is a potential management tool to control the continuing spread of these invasive species by suppressing spawning success. Future research should focus on further evaluation of the environmental cues that elicit spawning behaviors by monitoring movement patterns with telemetry and conventional sampling methods.

ACKNOWLEDGMENTS: This technical note was reviewed by Todd Slack and Alan Katzenmeyer, ERDC. The following ERDC personnel assisted in field studies during the 1990 and 2019 collections: Jay Collins, Neil Douglas, Jan Hoover, Bradley Lewis, Larry Sanders, and Todd Slack. Funding was provided by Vicksburg District, Kent Parrish Program Manager, and the ANSRP.

Cite this technical note as:

Killgore, K. Jack, and Steven G. George. 2021. Observation of Silver Carp Spawning in a Mississippi River Tributary. Aquatic Nuisance Species Research Program. ERDC/TN ANSRP-21-1. Vicksburg, MS: US Army Engineer Research and Development Center.

\section{REFERENCES}

Chick, J. H., D. K. Gibson-Reinemer, L. Soeken-Gittinger, and A. F. Casper. 2020. Invasive silver carp is empirically linked to declines of native sport fish in the Upper Mississippi River System. Biological Invasions 22: 723-734.

Degrandchamp, K. L., J. E. Garvey, and L. A. Csoboth. 2007. Linking adult reproduction and larval density of invasive carp in a large river. Transactions of the American Fisheries Society 136:1327-1334.

Deters, J. E., D. C. Chapman, and B. McElroy. 2013. Location and timing of Asian carp spawning in the Lower Missouri River. Environmental Biology of Fish 96:617-629.

Douglas, N. H., S. G. George, J. J. Hoover, K. J. Killgore, and W. T. Slack. 1996. Records of two Asian carps in the lower Mississippi Basin. Page 127 in Abstracts of the 76th Annual Meeting of the American Society of Ichthyologists and Herpetologists, University of New Orleans, New Orleans, LA.

Killgore, K. J. and S. G. George. 2020. Comparison of benthic fish assemblages along revetted and natural banks in the Lower Mississippi River: a 30-year perspective. MRG\&P Report 29, Mississippi River Geomorphology and Potamology 
Program, Mississippi Valley Division, Vicksburg, MS, 26 pp.

Kinlock, N. L., A. J. Laybourn, C. E. Murphy, J. J. Hoover, and N. A. Friedenberg. 2020. Modelling bioenergetic and population-level impacts of invasive bigheaded carps (Hypophthalmichthys spp.) on native paddlefish (Polyodon spathula) in backwaters of the lower Mississippi River. Freshwater Biology 65 (6): 1086-1100.

Kolar, C.S., D.C. Chapman, W.R. Courtenay, C.M. Housel, J.D. Williams, and D.P. Jennings. 2007. Bigheaded carps: a biological synopsis and environmental risk assessment. American Fisheries Society, Special Publication 33, Bethesda, Maryland, 204 pages.

Mueller, Jerry E. 1968. An introduction to the hydraulic and topographic sinuosity indexes. Annals of the Association of American Geographers 58:2, 371-385, DOI: 10.1111/j.1467-8306.1968.tb00650.x.

Ochs, C.A., O. Pongruktham, K.J. Killgore, and J.J. Hoover. 2019. Phytoplankton prey selection by the silver carp (Hypophthalmichthys molitrix Val.) in a Lower Mississippi River backwater. Southeastern Naturalist 18: 113-129.

Phelps, Q. E., S. J. Tripp, K. R. Bales, R. A. Hrabik, and D. P. Herzog DP. 2017. Incorporating basic and applied approaches to evaluate the effects of invasive Asian Carp on native fishes: A necessary first step for integrated pest management. PLoS ONE 12(9): https://doi.org/10.1371/journal.pone.0184081.

Pongruktham, O., C.A. Ochs and J.J. Hoover. 2010. Observations of Silver Carp (Hypophthalmichthys molitrix) Planktivory in a Floodplain Lake of the Lower Mississippi River Basin. Journal of Freshwater Ecology 25: 85-93.

Schrank S. J., C. S. Guy, and J. F. Fairchild. 2003. Competitive interactions between age-0 bighead carp and paddlefish. Trans Am Fish Soc. 132: 1222-1228.

Slack, W. T., S. G. George, J. J. Hoover, B. R. Lewis, A. W. Katzenmeyer, R. T. Ruth, and M. D. Wagner. 2016. Occurrence of bigheaded carps (Hypophthalmichthys spp.) in the Pearl River Drainage, Louisiana and Mississippi, USA. BioInvasions Records 5 (3): 159-168.

NOTE: The contents of this technical note are not to be used for advertising, publication, or promotional purposes. Citation of trade names does not constitute an official endorsement or approval of the use of such products. 